\title{
ASSESSING THE LEVEL OF IMPLEMENTATION OF LEAN CONSTRUCTION: AN AUDIT PROTOCOL
}

\author{
Marianna Lira Comelli ${ }^{1}$, Yan Mota Veras de Carvalho², Renan Caminha Marinho ${ }^{3}$, \\ Luis Felipe Cândido ${ }^{4}$ and José de Paula Barros Neto ${ }^{5}$
}

\begin{abstract}
The implementation of lean construction still faces barriers mainly in its initial stages. It occurs, in part, due to the lack of evaluation tools that enable the acknowledgment of its true value for the companies.

Thus, this paper aims to present an audit protocol to evaluate the level of lean implementation. Developed under Design Science methodological background, the audit protocol was proposed based on literature. To evaluate the applicability, the pilot protocol was implemented and tested into 4 construction companies from the city of Fortaleza, northeast of Brazil. The pilot revealed improvements to improve the protocol. Then, the improved protocol was evaluated and validated by 5 lean construction experts, resulting in the final protocol which was composed by 4 dimensions, 35 categories, 136 items and 223 examples of verifying evidences.

Was verified that the protocol allows more than identify the lean implementation level, but enables a lean journey if used as a guidebook to lean implementation. The proposed audit protocol can be also used to cyclic evaluation that enables the improvements of the identified gaps, through a deep comprehension of the critical factors that can prevent the success of lean construction in the companies.
\end{abstract}

\section{KEYWORDS}

Lean construction, improvement, evaluation tool, implementing lean, integration.

\section{INTRODUCTION}

Implement lean is a great challenge for any company from any sector. This is evident in the literature, since the efforts of Womack et al. (1990) that results in a generalization of Toyota principles, theoretically applicable in any company (Womack and Jones, 1996). Despite of this efforts, there is no consensus of this generalization, principally if

\footnotetext{
Professor, Christus University Center (UNICHRISTU), Brazil, marianacomelli@yahoo.com.br Master Student, Federal University of Ceará (UFC), Brazil, yanveras00@ gmail.com Master Student, Federal University of Ceará (UFC), Brazil, renancmarinho@gmail.com Lecturer, Federal University of Ceará (UFC) at Crateús, Brazil, luisfcandido2015@gmail.com Full Professor, Federal University of Ceará (UFC), Brazil, barrosneto@gercon.ufc.br
} 
considering the construction industry (Koskela, 2004). In construction industry, the application of Toyota principles are based in Koskela (1992), called as Lean Construction by founders of International Group for Lean Construction in 1993 (Koskela, 2004).

Since Koskela (1992), many researchers report the success and pitfalls of lean construction implementation (Ballard, 1993; Alarcón et al., 2005; Sarhan and Fox, 2013; Zanotti, Maranhão and Aly, 2017), indicating that the lean implementation question remains open. This question, can occur due to a poor vision of lean as a tool box (Atkinson, 2010) and because of the lack of evaluation tools that allows the acknowledgement of its true value for the companies (Li et al., 2015a; Cândido and Barros Neto, 2017).

Thus, an alternative to help companies to widespread implement lean in industry is evaluate implementation through audit protocol (see Karlsson and Ahlström (1996), Åhlström (1998), Soriano-Meier and Forrester (2002) and Bhasin (2011)). The use of tools to analyse lean implementation is an alternative for construction industry, as can be seen in previous IGLC proceedings as Diekmann et al. (2003), Hofacker et al. (2008), Valente et al. (2012), Etges et al. (2012, 2013), Nesensohn et al. (2014, 2015) and Li et al. (2015).

Although this apparent prolific literature, efforts to improve the lean implementation and its evaluation, remains a valuable initiative. Thus, this paper aims to present an audit protocol to evaluates the level of lean implementation. Developed under Design Science methodology background, the audit protocol was proposed based on literature.

The audit protocol to evaluates lean level of implementation was structured based on the 4P's (Liker, 2003): philosophy, process, people and partners and, finally, problem solving. This choice was taken due to the epistemological dispersion in the foundation of lean concepts in its different areas, as Krafcik (1988) seminal paper in the terminology of Lean Production System, Womack, Jones and Ross (1988) and later Womack and Jones (1996) used the terminology Lean Thinking and Koskela (1992) used Lean Construction. This dispersion can lead a misunderstood about of what is lean, as pointed by Koskela (2004). Finally, it is unanimous among the aforementioned authors that they are natural descendants of Toyota Production System (TPS), which justifies the choice of the TPS Pyramid proposed by Liker (2003) as framework of the audit protocol proposed.

\section{EVALUATING LEAN CONSTRUCTION IMPLEMENTATION LEVEL}

The implementation of lean construction in the construction industry generally presents strong barriers that can make it unfeasible, as it happens in the adhesion of other processes of organizational improvements. The adoption of lean construction demands investments and measurement of its benefits (Campos et al. 2012), which are frequently misunderstood and considered as shortcoming (Cândido and Barros Neto, 2017).

To correctly guide this process, the use of an efficient audit model in companies that use this philosophy of production management might/may contribute to operational efficiency of lean construction (Etges, Saurin and Bulhões, 2013). As an example in industry, Karlsson and Åhlström (1996), Soriano-Meier and Forrester (2002) and Bhasin (2011), proposes an evaluations to assess the Lean implementation and its benefits. In the 
construction industry, some authors also tried to evaluate the lean construction implementation level as showed in the Table 1.

Table 1: Models to evaluating the level of lean construction implementation published at

IGLC

\begin{tabular}{|c|c|c|c|c|c|c|}
\hline Author & $\begin{array}{l}\text { Dime } \\
\text { nsion } \\
\text { s }\end{array}$ & $\begin{array}{c}\text { Maturity } \\
\text { Level }\end{array}$ & $\begin{array}{c}\text { Evalua } \\
\text { tion }\end{array}$ & $\begin{array}{l}\text { Application/ } \\
\text { Validation }\end{array}$ & Strengths & Weakness \\
\hline $\begin{array}{l}\text { Diekma } \\
\text { nn et } \\
\text { al. } \\
(2003)\end{array}$ & 5 & No & $\begin{array}{l}\text { Organiz } \\
\text { ation }\end{array}$ & No & $\begin{array}{l}\text { - Justify the importance } \\
\text { of the evaluation } \\
\text { categories based on } \\
\text { literature }\end{array}$ & $\begin{array}{l}\text { - There is no application or } \\
\text { validation } \\
\text { - The categories are } \\
\text { evaluated superficially }\end{array}$ \\
\hline $\begin{array}{l}\text { Salem } \\
\text { et al. } \\
(2006)\end{array}$ & 6 & No & $\begin{array}{l}\text { Constru } \\
\text { ction } \\
\text { Site/ } \\
\text { Project }\end{array}$ & $\begin{array}{l}\text { Yes, a } \\
\text { unique } \\
\text { case study }\end{array}$ & $\begin{array}{l}- \text { Simplicity } \\
\text { - Relates the } \\
\text { expectations and the } \\
\text { currently level of } \\
\text { implementation of lean } \\
\text { tools }\end{array}$ & $\begin{array}{l}\text {-Limited number of lean } \\
\text { practices } \\
\text { - Unique case study }\end{array}$ \\
\hline $\begin{array}{l}\text { Hofack } \\
\text { er et al. } \\
\text { (2008) }\end{array}$ & 6 & 12 & $\begin{array}{l}\text { Organiz } \\
\text { ation }\end{array}$ & No & $\begin{array}{l}\text { - Simple and rapid to } \\
\text { applicate }\end{array}$ & $\begin{array}{l}\text {-Limited number of lean } \\
\text { practices } \\
\text { - There is no discussion } \\
\text { about each category }\end{array}$ \\
\hline $\begin{array}{l}\text { Campo } \\
\text { s et al. } \\
\text { (2012) }\end{array}$ & 06 & $\begin{array}{l}12 \text { to } \\
\text { lean } \\
\text { and } 5 \\
\text { for } \\
\text { sustain } \\
\text { ability }\end{array}$ & $\begin{array}{l}\text { Organiz } \\
\text { ation }\end{array}$ & $\begin{array}{l}\text { Yes, tow } \\
\text { application } \\
\mathrm{s}\end{array}$ & $\begin{array}{l}\text { - Relates the level of } \\
\text { lean implementation } \\
\text { with sustainability }\end{array}$ & $\begin{array}{l}\text { - There are no } \\
\text { improvements in } \\
\text { previously frameworks } \\
\text { used to evaluates lean as } \\
\text { well as sustainability }\end{array}$ \\
\hline $\begin{array}{l}\text { Valente } \\
\text { et al. } \\
\text { (2012) }\end{array}$ & 7 & No & $\begin{array}{l}\text { Constru } \\
\text { ction } \\
\text { Site/ } \\
\text { Project }\end{array}$ & $\begin{array}{l}\text { Yes, four } \\
\text { constructio } \\
\text { n sites }\end{array}$ & $\begin{array}{l}\text { - Enables a continuous } \\
\text { improvement for lean } \\
\text { practices } \\
\text { - Assume the variation of } \\
\text { level of leanness } \\
\text { according the } \\
\text { construction phase }\end{array}$ & $\begin{array}{l}\text { - Developed for a specific } \\
\text { company } \\
\text { - There is no external } \\
\text { validation } \\
\text { Focused only production } \\
\text { issues }\end{array}$ \\
\hline $\begin{array}{l}\text { Etges } \\
\text { et al. } \\
(2012 \text {, } \\
2013)\end{array}$ & 15 & No & $\begin{array}{l}\text { Organiz } \\
\text { ation }\end{array}$ & $\begin{array}{c}\text { Yes, } 18 \\
\text { experts } \\
\text { and } \\
\text { application } \\
\text { in a unique } \\
\text { case study }\end{array}$ & $\begin{array}{l}\text { - Robust and extensive } \\
\text { list of lean practices } \\
\text { - Demands different } \\
\text { source of evidence to } \\
\text { evaluate lean practices }\end{array}$ & $\begin{array}{l}\text { - Requires a lot of time- } \\
\text { consuming to apply (4 } \\
\text { hours) }\end{array}$ \\
\hline $\begin{array}{l}\text { Nesens } \\
\text { ohn et } \\
\text { al. } \\
(2014 \\
2015) \\
\end{array}$ & 11 & 5 & $\begin{array}{l}\text { Organiz } \\
\text { ation }\end{array}$ & $\begin{array}{c}\text { No, } \\
\text { validated } \\
\text { through } \\
\text { experts' } \\
\text { interviews } \\
\end{array}$ & $\begin{array}{l}\text { - Robust and extensive } \\
\text { list of lean practices } \\
\text { - Demands different } \\
\text { source of evidence to } \\
\text { evaluating lean practices }\end{array}$ & $\begin{array}{l}\text { - There is no external } \\
\text { validation } \\
\text { - There is no discussion } \\
\text { about each category }\end{array}$ \\
\hline $\begin{array}{l}\text { Li et al. } \\
\text { (2015) }\end{array}$ & 6 & No & $\begin{array}{l}\text { constru } \\
\text { ction } \\
\text { site/proj } \\
\text { ect }\end{array}$ & $\begin{array}{l}\text { Yes, } 300 \\
\text { projects }\end{array}$ & $\begin{array}{l}\text { - Extensive empirical } \\
\text { data collection } \\
\text { - Demands different } \\
\text { source of evidence to } \\
\text { evaluating lean practices }\end{array}$ & $\begin{array}{l}\text { - Measuring only the } \\
\text { results of lean and not its } \\
\text { really usage } \\
\text { - Limited number of lean } \\
\text { issues }\end{array}$ \\
\hline
\end{tabular}

Based on this literature, the dimensions were compared between them as well as the evaluation items, from which the pilot protocol was proposed. 


\section{METHOD}

This paper was developed under Design Science methodological background, based on Lukka (2003), Hevner et al. (2004) and Van Aken (2004). The research process is showed in Figure 1.

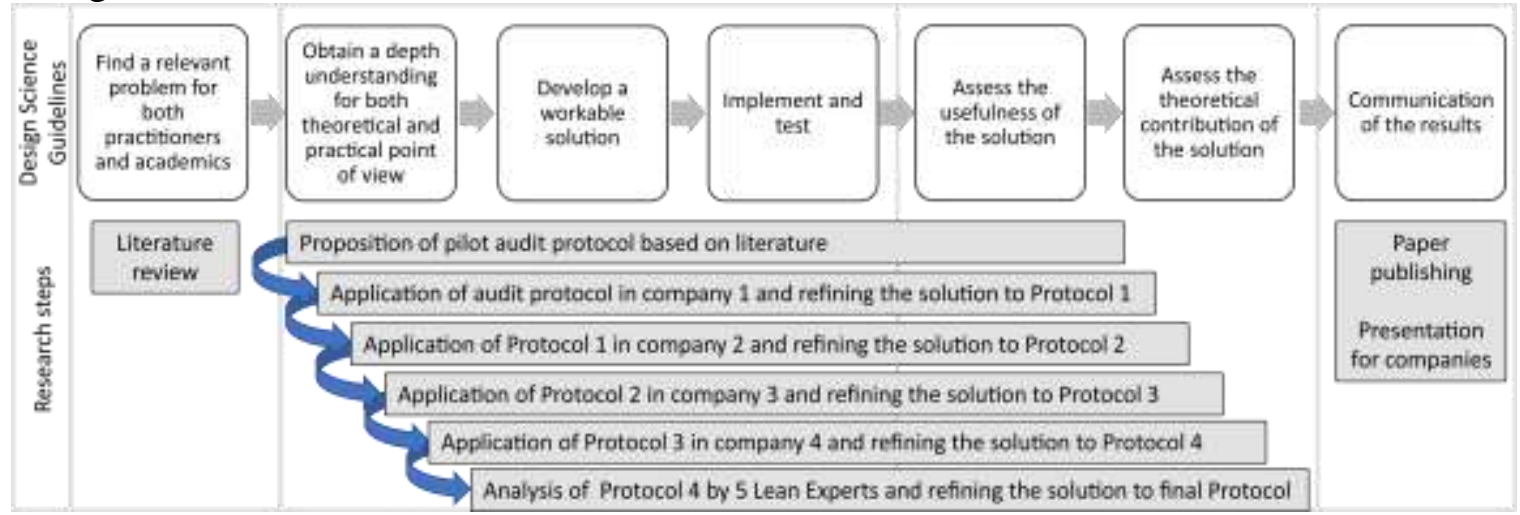

Figure 1 - Designed Research Process

Initially, a literature review was conducted focused in IGLC proceedings, from which five papers that proposes an evaluation of lean implementation was found. Through the exanimating of its references Salem et al. (2006) work was found and added into content analysis. Then, a pilot audit protocol was proposed based on literature and refined through four applications in four building companies from Fortaleza, city of Brazil. The main characteristics of the four companies are presented in Table 2 .

Table 2: Building companies' characterization

\begin{tabular}{ccccc}
\hline Company & Market segmentation & Age & $\begin{array}{c}\text { Time of lean } \\
\text { application }\end{array}$ & Interviewed \\
\hline A & $\begin{array}{c}\text { Residential, corporate and } \\
\text { industrial building }\end{array}$ & 37 years & 05 years & Planning Coordinator \\
B & $\begin{array}{c}\text { Residential and corporate } \\
\text { building }\end{array}$ & 23 years & 13 years & Planning Manager \\
C & $\begin{array}{c}\text { Residential and corporate } \\
\text { building }\end{array}$ & 29 years & 19 years & Technical Director \\
D & $\begin{array}{c}\text { Residential and industrial } \\
\text { building }\end{array}$ & 40 years & 13 years & $\begin{array}{c}\text { Lean and Green } \\
\text { Coordinator }\end{array}$ \\
\hline
\end{tabular}

In each of these cases were analysed the applicability and the understanding of the interviewees about the items of evaluation. Regardless of several types of evidence were requested and analysed, increasing understanding of how companies are fulfilling the items evaluated. Propositions of improvements for the audit protocol were performed, which increased the depth of understanding for both theoretical and practical point of view and the workable solution demanded by methodological background.

Finally, the interviewees analysed the usefulness of solution, they reached consensus about its useful. The main critic noticed by the interviewees was the high consumption of time for the audit process, about 2 hours. After the cycle of implementation, test and refining, the refined protocol was evaluated and validated by 5 lean construction experts (Table 3). 
Table 3: Lean construction expert characterization

\begin{tabular}{ccccc}
\hline Expert & Formal Education/ High degree & $\begin{array}{c}\text { Professional } \\
\text { Experience }\end{array}$ & $\begin{array}{c}\text { Level of LC } \\
\text { knowledge }\end{array}$ & $\begin{array}{c}\text { Involvement } \\
\text { with LC* }\end{array}$ \\
\hline A & $\begin{array}{c}\text { Bachelor's degree in civil engineering and } \\
\text { business administration, PhD in civil } \\
\text { engineering and post doctorate in } \\
\text { construction and housing economy }\end{array}$ & $\begin{array}{c}\text { 41 years, currently is } \\
\text { professor at State } \\
\text { University of Ceará }\end{array}$ & 10 & 7 \\
\hline B & $\begin{array}{c}\text { Bachelor's degree in civil engineering and } \\
\text { master's degree in industrial engineering }\end{array}$ & $\begin{array}{c}27 \text { years, currently is } \\
\text { Technical Director in } \\
\text { a building company }\end{array}$ & 8 & 8 \\
\hline C & $\begin{array}{c}\text { Bachelor's degree in civil engineering and } \\
\text { master's degree in industrial engineering }\end{array}$ & $\begin{array}{c}19 \text { years, currently is } \\
\text { Technical Director in } \\
\text { a building company }\end{array}$ & 8 & 10 \\
\hline D & $\begin{array}{c}\text { Bachelor's degree in architecture and } \\
\text { urbanism/ master's degree in civil } \\
\text { engineering and master's degree in } \\
\text { industrial engineering }\end{array}$ & $\begin{array}{c}\text { 10 years, currently is } \\
\text { architect at Federal } \\
\text { Institute of Ceará }\end{array}$ & 8 & 8 \\
\hline E & Bachelor's and master's degree in civil \\
engineering & $\begin{array}{c}\text { 08 years, currently is } \\
\text { professor at Federal } \\
\text { University of Ceará }\end{array}$ & 8 & 10 \\
\hline
\end{tabular}

Legend: * 0 to 10 .

Each expert evaluated the dimensions, categories, evaluation items and the scale of points. They approved the audit structure and scoring, however they suggested a rearrangement of categories and new items. Moreover, there is no consensus about the importance among each principle of Toyota pyramid suggested by Liker (2003). Finally, there was wide consensus among the interviewees about the applicability of the audit protocol, as well as its reliability for measuring the lean implementation level.

\section{PRESENTING THE AUDIT PROTOCOL TO EVALUATE THE LEVEL OF LEAN IMPLEMENTATION}

An audit protocol can be analysed as a performance measurement tool. Thus, the audit protocol can be structured in two components (Cândido, Lima and Barros Neto, 2016): architectural and processual framework. The architectural framework of the final audit protocol was structured in three levels of aggregation (Yu et al., 2007): dimensions (based on Toyota model), categories and evaluation items that need evidence in action. The processual framework was structured in three steps, based on Franco-Santos et al. (2007): (1) data collection and manipulation; (2) results communication and performance evaluation; (3) system review.

\section{ARCHITECTURE OF AUDIT PROTOCOL}

The characterization of audit protocol is presented in Table 4.

Table 4: Audit protocol characterization

\begin{tabular}{llll}
\hline Dimensions & Category & $\begin{array}{l}\text { Evaluation } \\
\text { items }\end{array}$ & $\begin{array}{l}\text { Source of } \\
\text { evidences }\end{array}$ \\
\hline \multirow{2}{*}{ Philosophy } & Lean Culture & 05 & 10 \\
\cline { 2 - 4 } & Lean Behavior & 06 & 11 \\
\cline { 2 - 4 } & Customer Focus & 07 & 15 \\
\hline
\end{tabular}




\begin{tabular}{|c|c|c|c|c|}
\hline & & Environment & 04 & 07 \\
\hline & & Waste management & 06 & 12 \\
\hline & & Wellbeing and safety work & 05 & 08 \\
\hline Subtotal & & 6 & 33 & 42 \\
\hline & & Work Flow & 11 & 19 \\
\hline & & Material & 09 & 18 \\
\hline & How & People & 03 & 05 \\
\hline & & Equipment & 03 & 05 \\
\hline & & Quality control & 05 & 09 \\
\hline & & Autonomation & 05 & 10 \\
\hline Process & Tonla & Standardized Work & 07 & 14 \\
\hline & 10015 & $5 S$ & 06 & 11 \\
\hline & & Transparency & 04 & 04 \\
\hline & & Knowledge and Information Management & 04 & 10 \\
\hline & & Design Planning and Control & 06 & 10 \\
\hline & Planning and & Production Planning and Control & 06 & 11 \\
\hline & & Cost Planning and Control & 06 & 11 \\
\hline & Subtotal & 23 & 75 & 137 \\
\hline & & Lean Leadership & 05 & 09 \\
\hline People & & Learning and growth of internal clients & 05 & 06 \\
\hline & & Learning and growth for supply chain & 06 & 08 \\
\hline Subtotal & & 03 & 16 & 23 \\
\hline & & Problem identification & 03 & 06 \\
\hline Problem & olving & Problem Solving & 03 & 05 \\
\hline & & Continuous improvement & 06 & 10 \\
\hline Total & & 03 & 12 & 21 \\
\hline Dimensi & ns: 04 & Categories: 35 & items: 136 & $\begin{array}{l}\text { evidences: } \\
223\end{array}$ \\
\hline
\end{tabular}

Due to the size of this paper, in following, we present an example of evaluation item in Table 5.

Table 5: Example of evaluation items to the dimension 'Philosophy' in the category "Lean Culture"

\begin{tabular}{|c|c|c|c|}
\hline Item & Question & Evidences & Reference \\
\hline 01 & $\begin{array}{l}\text { Does lean construction cover } \\
\text { all sectors of the company } \\
\text { from planning to execution of } \\
\text { the project? }\end{array}$ & $\begin{array}{l}\text { * Interview senior management to see if the } \\
\text { implementation of lean construction covers all } \\
\text { sectors of the company; } \\
\text { * Find out if the company has expert advice to } \\
\text { support the implementation of lean construction. }\end{array}$ & $\begin{array}{l}\text { Nesensohn } \\
\text { et al. (2015) }\end{array}$ \\
\hline \multicolumn{2}{|c|}{ ( ) Yes.Tot ( ) Yes.Part ( ) No ( ) N.A. } & \multicolumn{2}{|c|}{$\begin{array}{l}\text { What are the evidences that prove the attendance of the } \\
\text { question? }\end{array}$} \\
\hline 02 & $\begin{array}{l}\text { Is lean construction being } \\
\text { propagate as a strategic vision } \\
\text { of the business, and are all } \\
\text { constantly striving toward this } \\
\text { direction? }\end{array}$ & $\begin{array}{l}\text { * Interview top managers to see if the } \\
\text { implementation of lean construction is part of the } \\
\text { strategic planning of the company; } \\
\text { * Interview the senior management to find out if } \\
\text { is included in the financial investment plans of } \\
\text { the company, funds intended for the } \\
\text { implementation of lean construction. }\end{array}$ & $\begin{array}{l}\text { Hofacker et } \\
\text { al. (2008), } \\
\text { Carvalho } \\
(2008)\end{array}$ \\
\hline \multicolumn{2}{|c|}{ ( ) Yes.Tot ( ) Yes.Part ( ) No ( ) N.A. } & \multicolumn{2}{|c|}{$\begin{array}{l}\text { What are the evidences that prove the attendance of the } \\
\text { question? }\end{array}$} \\
\hline
\end{tabular}

The audit protocol is presented in full in Comelli (2018), a M.Sc. Dissertation, and as a supplementary document of this paper available at 〈http://bit.ly/2ILusOH $>$. 


\section{PROCESS OF AUDIT PROTOCOL}

As previously stated, the process of auditing was structured in three steps. The data collection and manipulation are conducted through interviews sections, documents and observations. Thereinafter, the score of evaluation is assigned according with Table 6.

Table : 6 Scores of evaluations item

\begin{tabular}{ccc}
\hline Evaluation item & Interpretation & Scores \\
\hline Fully implemented & The item is systematically evidenced in action & 1.0 \\
\hline Partially implemented & The item is inconsistent evidenced in action & 0.5 \\
\hline Not implemented & The item is hardly evidenced in action & 0.0 \\
\hline Not applicable & There is no applicability in the evaluation & Not computed \\
\hline
\end{tabular}

It should be noticed the difference between not implemented (zero) and not applicable (not computed). The Lean Construction implementation level in the particular dimension (LILD) is calculated as a percentage of scores obtained relative to maximum for each category. Thus, when an item is assigned as 'not implemented' he is not counted for the percentage. This option was made due to the difference among them (Table 4). For example, there is 33 evaluation items in Philosophy dimension and and 77 in Process dimension. Consequently, there is more possibilities to score in process dimension than Philosophy.

The results communication is initially exhibited through a radar chart, in which each axis corresponds to a dimension analysed, and a list of items from 'Partially implemented' to 'Not implemented' is presented, clarifying the opportunities of improvements. In Then, the LILD is calculated.

Based on the LILD achieved is provided a profile for the company (inspired in Succar (2009), from which is possible to classify into 4 categories as showed on Figure 2.

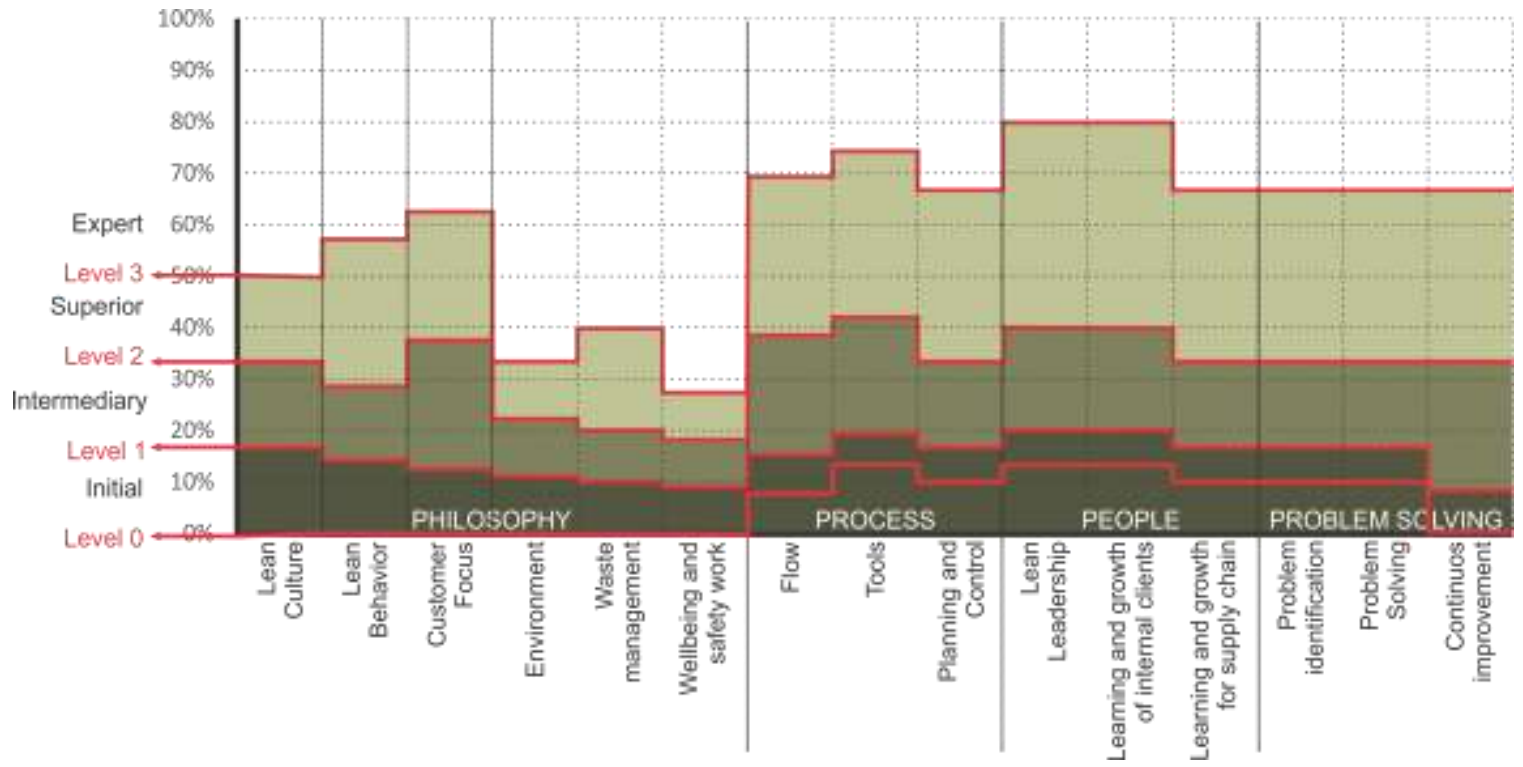

Figure 2: The final classification

Propose a profile, instead of an aggregate result, in the view of the authors it is more suitable because of the lack of agreement about the relative importance of each principle 
of TPS Pyramid. In a second reflection, it is hard to think in terms of practices hierarchization in different project contexts, which led the proposition of classification to be based on the sum of efforts to implement lean. For example, to a construction site located in an urban context, like housing build, it is easier to establish partnership with suppliers than in a road construction site. In vertical building construction is more important to invest in safety than in a simple house construction site.

Despite of this, in Liker (2003) is suggested majority of "Lean companies" are skating at process level. According to this author, to be "lean" is not copy the tools from Toyota in a specific production process. To be "Lean" is develop right principles to its own organization, in order to achieve a high performance of continuous value generating to the clients and society.

Based on that, it is possible to affirm that the use of Lean Tools does not characterize a company as lean, which originated the level zero in the proposed classification or pre-lean level. In this level are companies that reach until $10 \%$ of the practices listed on the audit protocol for process principles.

In the level 1, called as initial, is expected an early awareness formation in the top administration about the benefits of lean. This leads to commitment to lean deployment and consequently education to the other levels of the company - assuming a top-down approach. This early awareness is caused by visible and immediate result achieved by companies in its production process. The percentage of practices adopted to stablish this level was $20 \%$ of the practices to each category analysed.

It is worth to notice that $20 \%$ of evaluation items related with Lean Culture, with 05 items, corresponding a 1 practice, while to Flow, with 26 evaluation items, corresponding a 5. This justify different percentage into y-axes presented in Figure 2.

In the level 2, called as intermediary, is expected to advance up to $40 \%$ in all categories, which enables the early signals of a lean awareness in both mid and operational employees (internal clients). From this level of lean implementation, the philosophy permeates all company, although it does not reach the supply chain (external clients), which is expected in the level 3. Some initiatives aimed to buyers and end users (as customization) are under development as lean culture arises.

In the level 3, the lean awareness and practices are sedimented in the companies and to continue improving its performance its is necessary a step forth: integrates the external clients in the supply chain. At this time, is expected accomplishes the roles 1 and 2 of supply chain management in the construction industry, as proposed by Vrijhoef and Koskela (2000), e. g., intensification in development and improvement of specifics supply chains, such as prefabricated concrete elements. Moreover, mass customization and maintenance services to end users are implemented as the lean culture is sedimented. The percentage of practices adopted to stablish this level was $70 \%$.

In the expert category, is expected a prominent lean awareness and the atmosphere of the companies is founded in a Lean culture. As proposed by Liker (2003), in this level, the companies are capables to develop its own lean business model, i.e., new propositions and improvements arises and increase lean mentality itself. It is expected the accomplishment of the roles 3 and 4 of supply chain management (Vrijhoef and Koskela, 2000), as well as 
the involvement of clients and users in early stages of the construction project - conception and design of building.

It should be observed that the proposed methodology does not take into account, for the moment, if such management actions are successful. They are taken as successful at this stage to evaluate the actual level of lean implementation. Thus, the efficacy, efficiency and results of this actions are not the object of this evaluation.

The last step of the auditing is the system review. In this step, additional items of evaluation can be proposed by both practitioners and academics. In addition, any evaluation items can be removed, enabling the continuous improvement of the audit protocol. Moreover, as proposed by Franco-Santos et al. (2007), an evaluation tool should be flexible and upgradeable not only in terms of items of evaluation, but also in terms of the criterions of evaluation. Thus, the suggested scale can be refined whenever necessary.

\section{CONCLUSIONS}

This paper aims to present an audit protocol to evaluates the level of lean implementation. Thus, based on literature review a pilot audit protocol was proposed, which was applied and refined in four cycles into four building companies. Thereinafter, 5 lean experts criticize the protocol, refining it to definitive version.

Then, the final protocol was composed of 4 dimensions, 35 categories, 136 items and 223 examples of verifying evidences. As differential, the presented audit was developed in cooperation with both academic and practitioners, providing a widely and depth understand about lean construction that can helps in its implementation and diagnostic.

Moreover, the final protocol aims to support the lean implementation providing a diagnosis of the current stage and points out directions for a company to improve itself. During the Lean evolution is expected a gradual advance in all dimensions, mainly because the awareness formation pushed by Philosophy sedimentation that will press the others.

As a limitation, it should be observed that the proposed methodology does not take into account, for the moment, if such management actions are successful. Another type of evaluation is necessary for this analysis. Further, the audit protocol can be applied and analysed in different building companies to increases its value in future research.

To conclude, the proposed protocol contributes to better lean construction implementations, suggesting a huge amount of actions organized into TPS dimensions and introducing performance measurement criteria to evaluate them. In the end, through the proposed protocol the lean journey can be tracked by its agents and might prove the actual final purpose of its implementation for both clients and managers, supporting the institutionalization of lean construction in its companies.

\section{ACKNOWLEDGMENTSH}

We would like to thank CAPES for the financial support to this research. We would also like to thank the interviewees that participates and the GERCON. 


\section{REFERENCES}

Åhlström, P. (1998) 'Sequences in the implementation of lean production', European Management Journal, 16(3), pp. 327-334. doi: 10.1016/S0263-2373(98)00009-7.

van Aken, J. E. (2004) 'Management research on the basis of the design paradigm: The quest for field-tested and grounded technological rules', Journal of Management Studies, 41(2), pp. 219-246. doi: 0022-2380.

Alarcón, L. F. et al. (2005) 'Assessing the impacts of implementing lean construction', Proc. 13h Ann. Conf. of the Int'l. Group for Lean Construction, pp. 387-393. doi: 10.4067/S0718-50732008000100003.

Atkinson, P. (2010) “"Lean ” is a Cultural Issue', Management Services, summer 201, pp. 35-41.

Ballard, G. (1993) 'Lean construction and EPC performance improvement'. In: Alarcón, L. F. (1997) Lean Construction. Edited by L. F. Alarcón. CRC Press.

Bhasin, S. (2011) 'Measuring the Leanness of an organisation', International Journal of Lean Six Sigma, 2(1), pp. 55-74. doi: 10.1108/20401461111119459.

Campos, I. B., Oliveira, D. M. de, Carneiro, S. B. M., et al. (2012) 'Relation between the sustainable maturity of construction companies and the philosophy of lean construction' In: 20th Annual Conference of IGLC. San Diego, E.U.A: IGLC, 2012.

Campos, I.B. , Oliveira, D.M.D. , Carneiro, S.B.M. , Carvalho, A.B.L.D. \& Neto, J.P.B. 2012, 'Relation Between the Sustainable Maturity of Construction companies and the philosophy of lean construction' In:, Tommelein, I.D. \& Pasquire, C.L., 20th Annual Conference of the International Group for Lean Construction. San Diego, USA, 18-20 Jul 2012. Cândido, L.F. \& Neto, J.D.P.B. 2017, 'Features, Roles and Processes of Performance Measurement in Lean Construction' In:, 25th Annual Conference of the International Group for Lean Construction. Heraklion, Greece, 9-12 Jul 2017. pp 243250

Cândido, L. F., Lima, S. H. de O. and Barros Neto, J. de P. (2016) 'Análise de Sistemas de Medição de Desempenho na Indústria da Construção', Ambiente Construído, 16(2), pp. 189-208.

Carvalho, B. S. de (2008). Proposta de uma ferramenta de análise e avaliação das construtoras em relação ao uso da construção enxuta. $141 \mathrm{f}$. Dissertation (Master in Civil Engineering). Post-graduation programm in Civil Engingeering at Federal University of Paraná, Curitiba, 2008.Diekmann, J., Balonick, J., Krewedl, M. \& Troendle, L. 2003, 'Measuring Lean Conformance' In:, 11th Annual Conference of the International Group for Lean Construction. Virginia, USA, 1-.

Etges, B.M. , Saurin, T.A. \& Bulhões, I.R. 2012, 'Identifying Lean Construction Categories of Practices in the IGLC Proceedings' In:, Tommelein, I.D. \& Pasquire, C.L., 20th Annual Conference of the International Group for Lean Construction. San Diego, USA, 18-20 Jul 2012.

Etges, B.M.B.S. , Saurin, T.A. \& Bulhões, I.R. 2013, 'A Protocol for Assessing the Use of Lean Construction Practices' In:, Formoso, C.T. \& Tzortzopoulos, P., 21th Annual Conference of the International Group for Lean Construction. Fortaleza, Brazil, 31-2 Aug 2013. pp 93-101 
Franco-Santos, M. et al. (2007) 'Towards a definition of a business performance measurement system', International Journal of Operations \& Production Management, 27(8), pp. 784-801. doi: 10.1108/01443570710763778.

Hevner, A. R. et al. (2004) 'Design Science in Information Systems Research', Mis Quarterly, 32(1), pp. 725-730.Hofacker, A. , Oliveira, B.F.D. , Gehbauer, F. , Freitas, M.C.D. , Menez, Jr., R. , Santos, A. \& Kirsch, J. 2008, 'Rapid Lean ConstructionQuality Rating Model (LCR)' In:, Tzortzopoulos, P. \& Kagioglou, M., 16th Annual Conference of the International Group for Lean Construction. Manchester, UK, 16-18 Jul 2008. pp 241-250

Karlsson, C. and Ahlström, P. (1996) 'Assessing changes towards lean production', International Journal of Operations and management, 16(2), pp. 24-41.

Koskela, L. (1992) Application of the new production philosophy to construction. Techniccal Repport 72. Center for Integrated Facility Engineering. Department of Civil Engineering. Stanford Univeristy.

Koskela, L. (2004) 'Moving on - beyond lean thinking', Lean Construction Journal, 1(1, october), pp. 24-37.

Krafcik, J. F. (1988) 'Triumph of the lean production system', Sloan Management Review, 30(1), p. 41. doi: 10.1108/01443570911005992.Li, S. , Wu, X. , Hu, S. \& Hu, B. 2015, 'Performance Evaluation of Lean Construction Projects Based on Balanced Scorecard' In:, Seppänen, O., González, V.A. \& Arroyo, P., 23rd Annual Conference of the International Group for Lean Construction. Perth, Australia, 29-31 Jul 2015. pp 753762

Liker, J. K. (2003) The Toyota Way: 14 Management Principles from the World's Greatest Manufacturer. McGraw-Hill Education.

Lukka, K. (2003) 'The constructive research approach', in Ojala, L. and Hilmola, O.-P. (eds) Case study research in logistics. Turku: Turku School of Economics and Business Administration, pp. 83-101.Nesensohn, C. , Bryde, D. , Ochieng, E. , Fearon, D. \& Hackett, V. 2014, 'Assessing Lean Construction Maturity' In:, Kalsaas, B.T., Koskela, L. \& Saurin, T.A., 22nd Annual Conference of the International Group for Lean Construction. Oslo, Norway, 25-27 Jun 2014. pp 1157-1168

Nesensohn, C. , Bryde, D. \& Pasquire, C. 2015, 'A Measurement Model for Lean Construction Maturity' In:, Seppänen, O., González, V.A. \& Arroyo, P., 23rd Annual Conference of the International Group for Lean Construction. Perth, Australia, 29-31 Jul 2015. pp 652-660

Salem, O. et al. (2006) 'Lean Construction: From Theory to Implementation', Journal of Management in Engineering, 22(4), pp. 168-175. doi: 10.1061/(ASCE)0742597X(2006)22:4(168).

Sarhan, S. and Fox, A. (2013) 'Barriers to Implementing Lean Construction in the UK Construction Industry', The Built \& Human Environment Review, 6, pp. 1-17.

Soriano-Meier, H. and Forrester, P. L. (2002) 'A model for evaluating the degree of leanness of manufacturing firms', Integrated Manufacturing Systems, 13(2), pp. 104109. doi: 10.1108/09576060210415437.Succar, B. (2009) 'Building information modelling framework: A research and delivery foundation for industry stakeholders', Automation in Construction, 18(3), pp. 357-375. doi: 10.1016/j.autcon.2008.10.003. 
Valente, C.P. , Novaes, M.D.V. , Mourão, C.A.M.D.A. \& Neto, J.D.P.B. 2012, 'Lean Monitoring and Evaluation in a Construction Site: A Proposal of Lean Audits' In:, Tommelein, I.D. \& Pasquire, C.L., 20th Annual Conference of the International Group for Lean Construction. San Diego, USA, 18-20 Jul 2012.

Vrijhoef, R. and Koskela, L. (2000) 'The four roles of supply chain management in construction', European Journal of Purchasing \& Supply Management, 6(3-4), pp. 169-178. doi: 10.1016/S0969-7012(00)00013-7

Womack, J. P. and Jones, D. T. (1996) Lean Thinking: Banish Waste \& Create Wealth in your Corporation. New York: Free Press.

Womack, J. P., Jones, D. T. and Ross, D. (1990) The Machine That Changed the World. Free Press.

Yu, I. et al. (2007) 'Comparable Performance Measurement Sytem for Construction Companies', Journal of Management in Engineering, 23(3), pp. 131-139.

Zanotti, N.L. , Maranhão, F.L. \& Aly, V.L.C. 2017, 'Bottom-up Strategy for Lean Construction on Site Implementation' In:, 25th Annual Conference of the International Group for Lean Construction. Heraklion, Greece, 9-12 Jul 2017. pp 325-331. 